Article

\title{
In Vitro Cytotoxicity Induced by the Bufadienolides $1 \alpha, 2 \alpha$-Epoxyscillirosidine and Lanceotoxin B on Rat Myocardial and Mouse Neuroblastoma Cell Lines
}

\author{
Danielle Henn, Annette Venter and Christo Botha * \\ Department of Paraclinical Sciences, Faculty of Veterinary Science, University of Pretoria, Onderstepoort 0110, \\ South Africa; DanielleHenn@tuks.co.za (D.H.); annette.venter@up.ac.za (A.V.) \\ * Correspondence: christo.botha@up.ac.za
}

Received: 26 November 2018; Accepted: 23 December 2018; Published: 2 January 2019

\begin{abstract}
Consumption of bufadienolide-containing plants are responsible for many livestock mortalities annually. Bufadienolides are divided into two groups; non-cumulative bufadienolides and cumulative bufadienolides. Cumulative bufadienolides are referred to as neurotoxic, as the chronic intoxication with this type of bufadienolide results in a paretic/paralytic syndrome known as 'krimpsiekte'. The in vitro cytotoxicity of a non-cumulative bufadienolide, $1 \alpha, 2 \alpha-$ epoxyscillirosidine, and a cumulative bufadienolide, lanceotoxin $\mathrm{B}$, were compared using the MTT ((3-(4,5-dimethylthiazol-2-yl)-2,5-diphenyltetrazolium bromide reduction) assay after exposing rat myocardial $(\mathrm{H} 9 \mathrm{c} 2)$ and mouse neuroblastoma (Neuro-2a) cell lines. The effect of these two bufadienolides on cell ultrastructure was also investigated using transmission electron microscopy (TEM). H9c2 cells exhibited greater cytotoxicity when exposed to $1 \alpha, 2 \alpha$-epoxyscillirosidine, compared to lanceotoxin B. In contrast, Neuro-2a cells were more susceptible to lanceotoxin B. The $\mathrm{EC}_{50}$ (half maximal effective concentration) of lanceotoxin B exposure of Neuro-2a cells for 24-72 $\mathrm{h}$ ranged from 4.4-5.5 $\mu \mathrm{M}$ compared to $\mathrm{EC}_{50} \mathrm{~s}$ of 35.7-37.6 $\mu \mathrm{M}$ for $1 \alpha, 2 \alpha$-epoxyscillirosidine exposure of Neuro-2a cells over the same period. $1 \alpha, 2 \alpha$-Epoxyscillirosidine induced extensive vacuolization in both cell types, with swollen RER (rough endoplasmic reticulum) and perinuclear spaces. Lanceotoxin B caused swelling of the mitochondria and sequestration of cytoplasmic material within autophagic vesicles. These results corroborate the notion that cumulative bufadienolides are neurotoxic.
\end{abstract}

Keywords: cumulative bufadienolide; cytotoxicity; $1 \alpha, 2 \alpha$-epoxyscillirosidine; lanceotoxin B; neurotoxic; ultrastructure

Key Contribution: Based on the MTT assay and ultrastructural changes observed; when compared to the non-cumulative bufadienolide $1 \alpha, 2 \alpha$-epoxyscillirosidine; the cumulative bufadienolide lanceotoxin $\mathrm{B}$ can be considered neurotoxic.

\section{Introduction}

Cardiac glycosides are found in plants worldwide and based on their chemical structure are classified as either bufadienolides or cardenolides. Bufadienolide-containing plants are considered as one of the greatest causes of plant-associated poisoning of livestock in South Africa [1]. Bufadienolides are C-24 steroids with a double unsaturated six-membered lactone ring attached to C-17 $\beta$. Bufadienolides can be further divided into non-cumulative and cumulative bufadienolides [2]. Depending on the type and dose of the bufadienolide-containing plant ingested by the animal, poisoning can manifest as either acute or chronic intoxication.

Non-cumulative bufadienolides cause acute cardiac glycoside poisoning in animals, which affects the cardiovascular, gastrointestinal, respiratory and nervous systems. These non-cumulative 
bufadienolides can be found in plants belonging to the genera Moraea and Drimia, among others. Moraea pallida (yellow tulip) is well known for causing livestock poisoning and contains the non-cumulative bufadienolide $1 \alpha, 2 \alpha$-epoxyscillirosidine as its main toxic principle [3].

In contrast, cumulative bufadienolides can cause either acute or chronic intoxication depending on the dose and are present in the plants of the family Crassulaceae ('plakkies'), specifically from the genera Tylecodon, Cotyledon and Kalanchoe [2]. Although bufadienolide-containing plants have a worldwide distribution, plants containing cumulative bufadienolides have, to date, only been reported in Southern Africa. During chronic intoxication the clinical signs associated with the cardiovascular, gastrointestinal and respiratory systems are less apparent, while the nervous signs predominate. The chronic form of intoxication is a paretic condition known colloquially as 'krimpsiekte' and occurs most often in small stock [1]. Affected animals assume a characteristic posture, from which the name 'krimpsiekte' is derived, by standing with their back arched, feet together and head bowed down. Lanceotoxin B is a cumulative bufadienolide, isolated from Kalanchoe lanceolata, reportedly causing krimpsiekte in sheep and has a subcutaneous $\mathrm{LD}_{50}$ (half maximal lethal dose) of $0.10 \mathrm{mg} / \mathrm{kg}$ in guinea-pigs [4].

All cardiac glycosides, including bufadienolides, act by inhibiting the $\mathrm{Na}^{+} / \mathrm{K}^{+}$-ATPase (sodium/potassium-adenosine triphosphatase) causing an increase in the intracellular sodium concentration of the cell and subsequently indirectly inhibiting the $\mathrm{Na}^{+} / \mathrm{Ca}^{2+}$-exchanger. The ability of the $\mathrm{Na}^{+} / \mathrm{K}^{+}$-ATPase to act as a scaffold protein that regulates downstream effectors, as well as the increase in intracellular calcium, allow the cardiac glycoside to trigger various cell signaling pathways [5]. These pathways then proceed to influence cellular functions such as proliferation, cell death mechanisms, protein synthesis and cellular metabolism [5], and even cellular attachment [6,7]. In addition, it was proposed that cumulative bufadienolides can bind to the nicotinic acetylcholine receptors of the neuromuscular junction and that this is what causes the neuromuscular dysfunction [8]. Based on the cholinergic activity, it was hypothesized that cumulative bufadienolides occupy the neuromuscular receptors, decreasing their functionality. With continuous discharge, the acetylcholine stores of the motor nerve terminal are eventually depleted, and the remaining receptors are occupied with acetylcholine, desensitizing the receptors to further stimulation; as a result, fatigue sets in. This leads to the myasthenia gravis-like weakness seen in affected animals. Chronic intoxication with the cumulative bufadienolide, cotyledoside, has been shown to cause lesions in the white matter of thalamic nuclei, explaining some of the motor function deficiencies seen in affected animals [9].

The objective of this study was to investigate the in vitro cytotoxicity induced by $1 \alpha, 2 \alpha$ epoxyscillirosidine and lanceotoxin B on rat myocardial (H9c2) and mouse neuroblastoma (Neuro-2a) cell lines, to lend credence to the premise that cumulative bufadienolides are neurotoxic. Additionally, the ultrastructural changes caused by the non-cumulative and cumulative bufadienolide respectively, was investigated using electron microscopy.

\section{Results}

\subsection{The Cytotoxicity of $1 \alpha, 2 \alpha$-Epoxyscillirosidine and Lanceotoxin B on H9c2 and Neuro-2a Cell Lines}

The viability of $\mathrm{H} 9 \mathrm{c} 2$ and Neuro-2a cells after exposure to a serial dilution of $1 \alpha, 2 \alpha-$ epoxyscillirosidine and lanceotoxin B for 24,48 and $72 \mathrm{~h}$ were examined using the MTT ((3- $(4,5-$ dimethylthiazol-2-yl)-2,5-diphenyltetrazolium bromide reduction) viability assay.

When exposed to $\mathrm{H} 9 \mathrm{c} 2$ cells, $1 \alpha, 2 \alpha$-epoxyscillirosidine induced a time-dependent effect, with decreasing $\mathrm{EC}_{50} \mathrm{~s}$ after 24,48 and $72 \mathrm{~h}$ exposure respectively (Table 1 ). The non-cumulative bufadienolide had a concentration-dependent effect as well with the percentage cell survival decreasing with higher toxin concentrations as depicted in the non-linear regression curves (Figure 1). A hormetic effect at low $1 \alpha, 2 \alpha$-epoxyscillirosidine concentrations was observed, with cell survival increasing to above that of the solvent control. In contrast to $1 \alpha, 2 \alpha$-epoxyscillirosidine, lanceotoxin $B$ had a less potent effect on the $\mathrm{H} 9 \mathrm{c} 2$ cells (Figure 1), with an $\mathrm{EC}_{50}$ greater than $200 \mu \mathrm{M}$ at $24 \mathrm{~h}$ with the $95 \% \mathrm{CI}$ (confidence interval) 
falling between $64 \%$ and $92 \%$ cell survival (Table 1 ). At $48 \mathrm{~h}$, the $\mathrm{EC}_{50}$ was around $200 \mu \mathrm{M}$ with a $95 \%$ $\mathrm{CI}$ of between $49 \%$ and $68 \%$ cell survival and finally, at $72 \mathrm{~h}$ the $\mathrm{EC}_{50}$ was below $200 \mu \mathrm{M}$ with the $95 \%$ CI falling between $36 \%$ and $48 \%$ cell survival. A significant concentration-dependent effect could be seen at 48 and $72 \mathrm{~h}$ exposure, with the percentage cell survival decreasing with higher lanceotoxin B concentrations. At $24 \mathrm{~h}$ however, the concentration dependent effect was not significant.

Table 1. The $\mathrm{EC}_{50}$ of $1 \alpha, 2 \alpha$-epoxyscillirosidine and lanceotoxin B on $\mathrm{H} 9 \mathrm{c} 2$ and Neuro-2a cells after 24, 48 and $72 \mathrm{~h}$ exposure.

\begin{tabular}{|c|c|c|c|c|}
\hline Cell Lines & Bufadienolide & $24 \mathrm{~h}$ & $48 \mathrm{~h}$ & $72 \mathrm{~h}$ \\
\hline $\mathrm{H} 9 \mathrm{c} 2$ & $\begin{array}{c}1 \alpha, 2 \alpha \text {-Epoxyscillirosidine } \\
\text { Lanceotoxin B }\end{array}$ & $\begin{array}{c}41.39 \pm 4.37 \mu \mathrm{M} \\
n=3 \\
>200 \mu \mathrm{M} \\
(95 \% \text { CI: } 64-92) * \\
n=4\end{array}$ & $\begin{array}{c}25.42 \pm 3.73 \mu \mathrm{M} \\
n=3 \\
\sim 200 \mu \mathrm{M} \\
(95 \% \mathrm{CI}: 49-68) * \\
n=4\end{array}$ & $\begin{array}{c}12.65 \pm 2.75 \mu \mathrm{M} \\
n=3 \\
<200 \mu \mathrm{M} \\
(95 \% \text { CI: } 36-48) * \\
n=4\end{array}$ \\
\hline Neuro-2a & $\begin{array}{c}1 \alpha, 2 \alpha \text {-Epoxyscillirosidine } \\
\text { Lanceotoxin B }\end{array}$ & $\begin{array}{c}35.73 \pm 10.59 \mu \mathrm{M} \\
n=3 \\
5.46 \pm 0.37 \mu \mathrm{M} \\
n=4\end{array}$ & $\begin{array}{c}37.56 \pm 3.18 \mu \mathrm{M} \\
n=3 \\
5.27 \pm 0.59 \mu \mathrm{M} \\
n=4\end{array}$ & $\begin{array}{c}37.35 \pm 2.30 \mu \mathrm{M} \\
n=3 \\
4.43 \pm 0.67 \mu \mathrm{M} \\
n=4\end{array}$ \\
\hline
\end{tabular}

$\mathrm{EC}_{50}(\mu \mathrm{M}) \pm$ Standard error of the mean for at least three biological repeats $(n) .{ }^{*}$ At $200 \mu \mathrm{M}$ the percentage cell survival fell between that indicated in brackets with a $95 \%$ confidence interval.
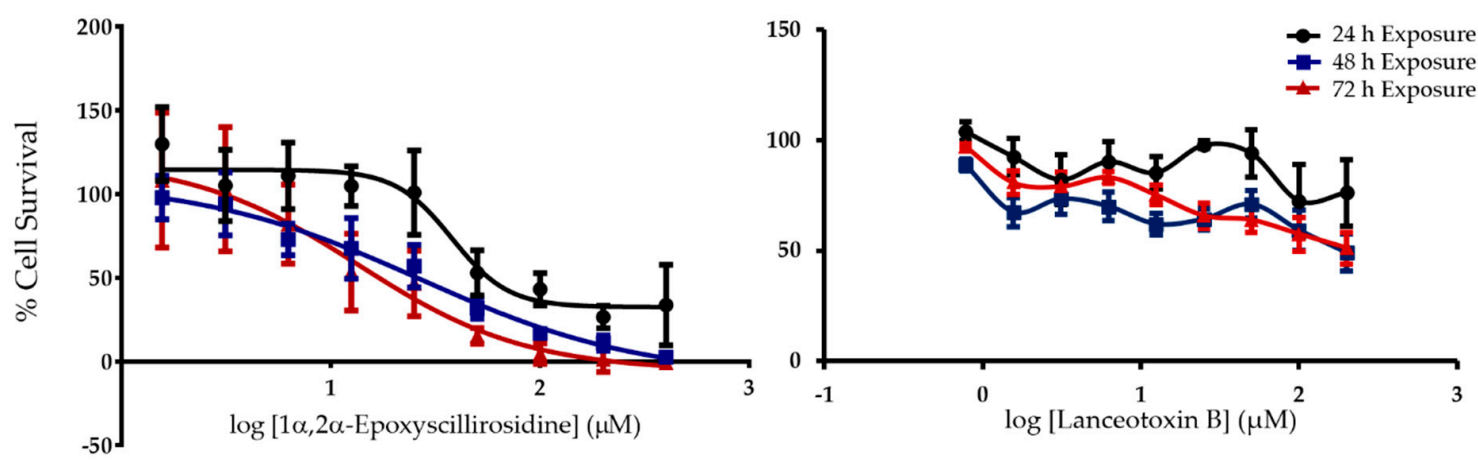

Figure 1. The semi-log concentration response curves of $1 \alpha, 2 \alpha$-epoxyscillirosidine and lanceotoxin $\mathrm{B}$ on $\mathrm{H} 9 \mathrm{c} 2$ cells for 24,48 and $72 \mathrm{~h}$ exposure expressed as percentage cell survival compared to the solvent control. Error bars indicate standard error of the mean.

When Neuro-2a cells were exposed to $1 \alpha, 2 \alpha$-epoxyscillirosidine, there were no significant time-dependent effects between the $\mathrm{EC}_{50} \mathrm{~s}$ at 24,48 and $72 \mathrm{~h}$ exposure. The $\mathrm{EC}_{50} \mathrm{~s}$ of $1 \alpha, 2 \alpha-$ epoxyscillirosidine did not significantly differ between exposure times (Table 1). The percentage cell survival decreased with higher $1 \alpha, 2 \alpha$-epoxyscillirosidine concentrations as shown with the non-linear regression curves (Figure 2). Lanceotoxin B had $\mathrm{EC}_{50}$ s below $10 \mu \mathrm{M}$ for all exposure times (Table 1). As with $1 \alpha, 2 \alpha$-epoxyscillirosidine, lanceotoxin B showed a clear concentration dependent effect, with higher concentrations reducing the Neuro-2a cell survival (Figure 2). 


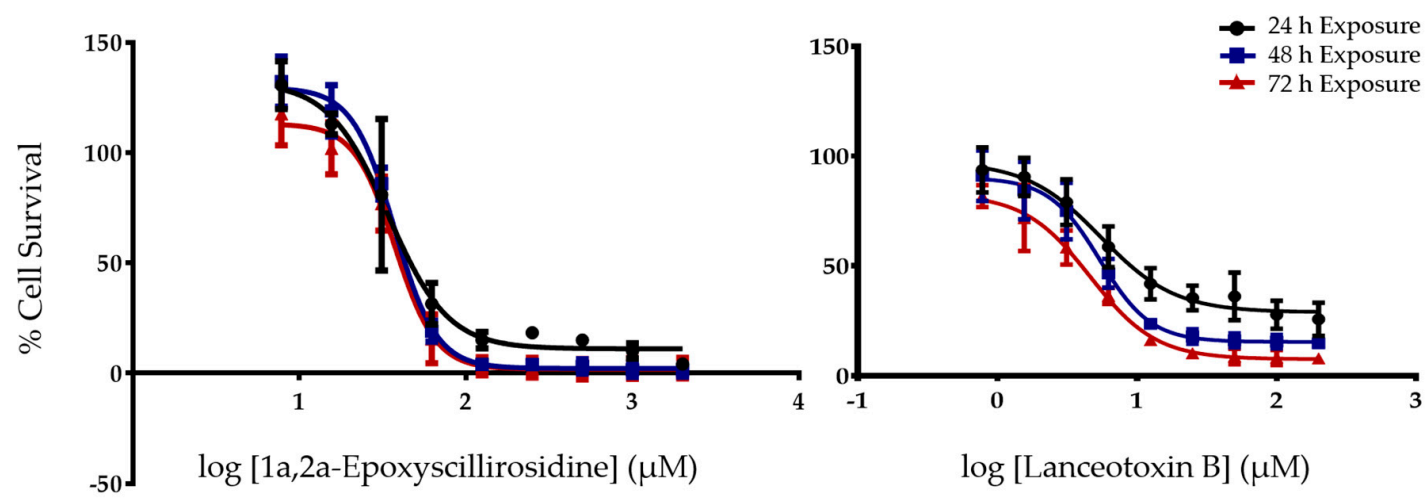

Figure 2. The semi-log concentration response curves of $1 \alpha, 2 \alpha$-epoxyscillirosidine and lanceotoxin B on Neuro-2a cells for 24,48 and $72 \mathrm{~h}$ exposure expressed as percentage cell survival compared to the solvent control. Error bars indicate standard error of the mean.

\subsection{The Effect of $1 \alpha, 2 \alpha$-Epoxyscillirosidine and Lanceotoxin B on H9c2 and Neuro-2a Cell Line Ultrastructure}

The ultrastructure of $\mathrm{H} 9 \mathrm{c} 2$ and Neuro-2a cells after exposure to either $1 \alpha, 2 \alpha$-epoxyscillirosidine or lanceotoxin B for $24 \mathrm{~h}, 48 \mathrm{~h}$ and $72 \mathrm{~h}$ was investigated using TEM. Untreated H9c2 cells were long, thin and tapered at both ends (Figure 3a,b). The cytoskeleton was associated with the plasma membrane (black arrows), and nuclei were round or oval shaped. The RER, Golgi complexes and mitochondria were normal. After exposure to $1 \alpha, 2 \alpha$-epoxyscillirosidine the Golgi complexes and RER became swollen, with ribosomes dissociating from the RER (Figure 3c). The plasma membrane of the cells was damaged (Figure 3d), with some cellular debris visible. The nuclei were affected with swollen perinuclear spaces (red arrows; Figure 3e) and the nuclear material condensing at 48 and $72 \mathrm{~h}$ exposure. Autophagic vesicles (blue arrow heads; Figure 3c,e) could be seen distributed throughout the cell and the cytoplasm of the cells was extensively vacuolated (Figure 3f).

The H9c2 cells exposed to lanceotoxin B had slightly swollen Golgi complexes (red square), while the RER remained unaffected (Figure 4a). The number of autophagic vesicles in the cytoplasm increased (blue arrow heads; Figure 4a). Many cells were shrunken, rounded and formed plasma membrane blebs indicative of apoptosis (pink arrows; Figure 4a). The mitochondria were damaged and became grossly swollen after longer exposure periods (Figure $4 \mathrm{~d}$ ). The nuclei appeared unaffected, but with some having electron-dense aggregates in the nucleoplasm (red circles; Figure 4b). The plasma membrane and associated cytoskeleton was disrupted (black arrows; Figure 4c). 

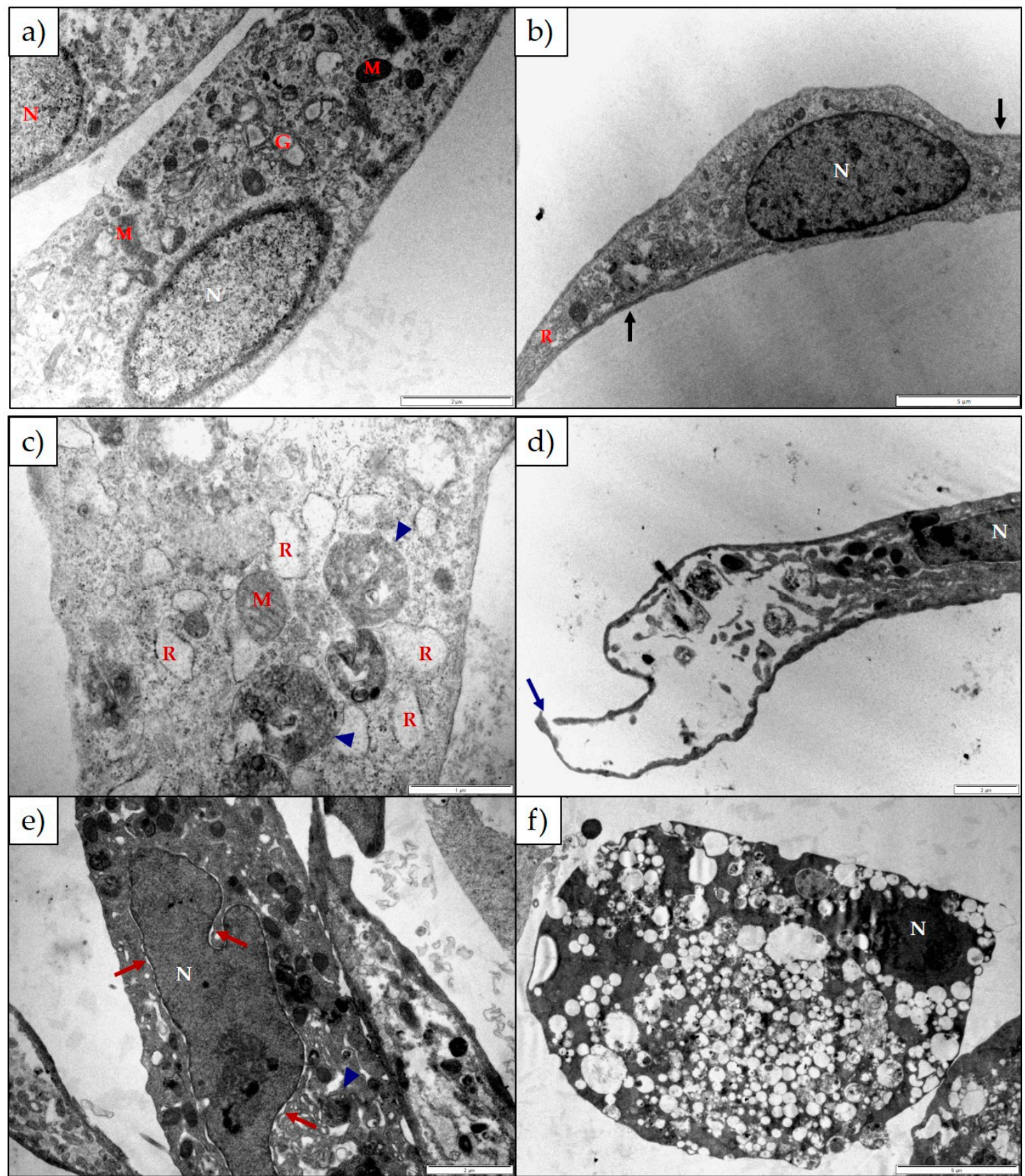

Figure 3. Electron micrograph of (a,b) untreated $\mathrm{H} 9 \mathrm{c} 2$ cells and $\mathrm{H} 9 \mathrm{c} 2$ cells exposed to (c) $25 \mu \mathrm{M}$ and (d) $100 \mu \mathrm{M} 1 \alpha, 2 \alpha$-epoxyscillirosidine for $24 \mathrm{~h}$; (e) $100 \mu \mathrm{M} 1 \alpha, 2 \alpha$-epoxyscillirosidine for $48 \mathrm{~h}$; (f) $100 \mu \mathrm{M} 1 \alpha, 2 \alpha$-epoxyscillirosidine for $72 \mathrm{~h}$. The untreated cells were long and thin with tapered ends. The cytoskeleton was associated with the plasma membrane (black arrows). The H9c2 cells treated with $1 \alpha, 2 \alpha$-epoxyscillirosidine has plasma membrane damage (blue arrow), swollen RER and perinuclear spaces (red arrows) and cells were extensively vacuolated. Autophagic vesicles could be seen within the cytoplasm (blue arrow heads). G-Golgi Complexes; M-Mitochondria; N-Nuclei; R-Rough Endoplasmic Reticulum. The scale bar at the bottom right corner represents $5 \mu \mathrm{m}(\mathbf{b}, \mathbf{f}), 2 \mu \mathrm{m}(\mathbf{a}, \mathbf{d}, \mathbf{e})$ and $1 \mu \mathrm{m}(\mathbf{c})$ respectively. 


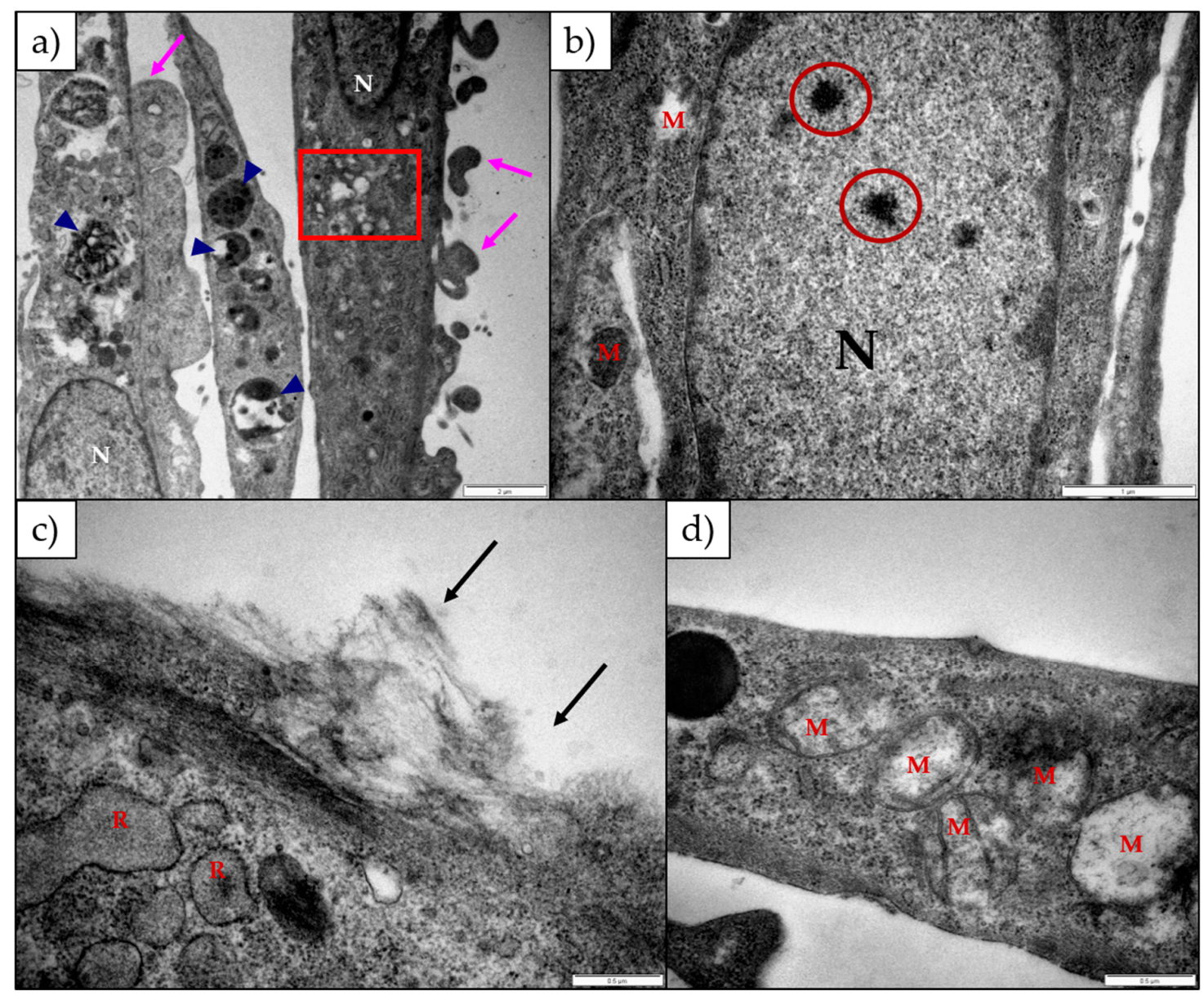

Figure 4. Electron micrograph of H9c2 cells exposed to (a) $25 \mu \mathrm{M}$ and (b) $100 \mu \mathrm{M}$ lanceotoxin B for $24 \mathrm{~h}$; (c) $5 \mu \mathrm{M}$ lanceotoxin B for $48 \mathrm{~h}$; (d) $100 \mu \mathrm{M}$ lanceotoxin B for $72 \mathrm{~h}$. The cytoplasm contained autophagic vesicles (blue arrow heads), swollen Golgi complexes (red square) and swollen mitochondria (d). The nuclei were normal, except for some aggregates in the nucleoplasm (red circles). The cells formed plasma membrane blebs (pink arrows) and the cytoskeleton associated with the plasma membrane was disrupted (black arrows). M-Mitochondria; N-Nuclei; R-Rough Endoplasmic Reticulum. The scale bar at the bottom right corner represents $2 \mu \mathrm{m}(\mathbf{a}), 1 \mu \mathrm{m}(\mathbf{b})$ and $0.5 \mu \mathrm{m}(\mathbf{c}, \mathbf{d})$ respectively.

Untreated Neuro-2a cells had clear Golgi complexes, mitochondria surrounded by RER and few autophagic vesicles within the cytoplasm (Figure 5a,b). Nuclei were round, with a few having a more convoluted shape. In contrast, Neuro-2a cells exposed to $1 \alpha, 2 \alpha$-epoxyscillirosidine for 24 , 48 and $72 \mathrm{~h}$ indicated slightly swollen Golgi complexes, with swollen RER. Ribosomes dissociated from the RER and aggregated in the cytoplasm (Figure 5c). The nuclei of Neuro-2a cells exposed to $100 \mu \mathrm{M}$ of $1 \alpha, 2 \alpha$-epoxyscillirosidine were radially segmented or irregularly shaped (Figure $5 \mathrm{a}$ ). The cytoplasm was extensively vacuolated (Figure $5 c, d$ ), with autophagic vesicles (blue arrow heads; Figure $5 \mathrm{c}, \mathrm{f})$ being distributed throughout the cytoplasm. The mitochondria were damaged, while some had ballooned cristae (blue box; Figure 5e). As with the H9c2 cells, the nuclei of Neuro-2a cells exposed to $1 \alpha, 2 \alpha$-epoxyscillirosidine had swollen perinuclear spaces (red arrows; Figure 5e). 

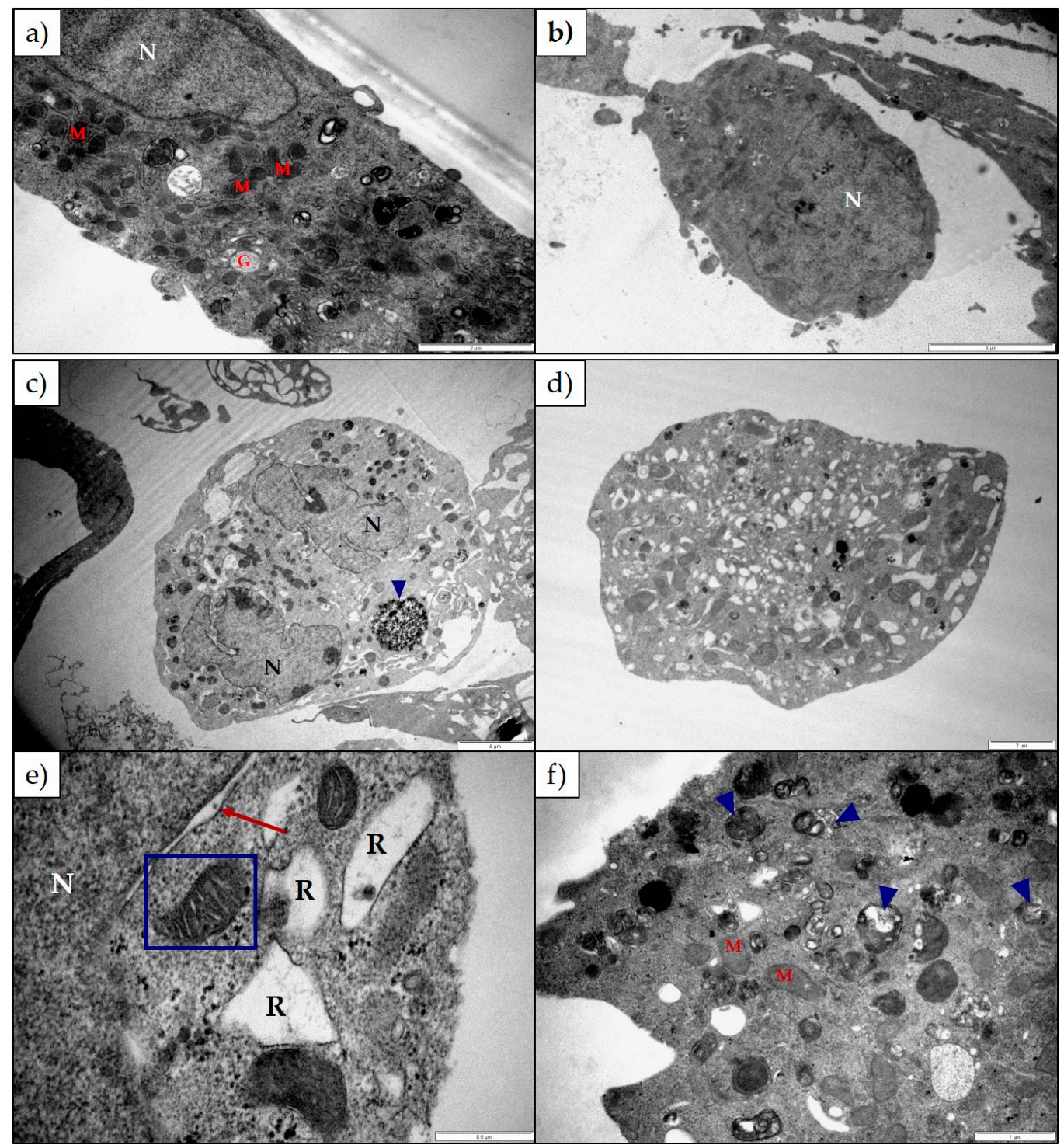

Figure 5. Electron micrograph of $(\mathbf{a}, \mathbf{b})$ untreated Neuro-2a cells and Neuro-2a cells exposed to (c) $100 \mu \mathrm{M} 1 \alpha, 2 \alpha$-epoxyscillirosidine for $24 \mathrm{~h}$; (d,e) $100 \mu \mathrm{M} 1 \alpha, 2 \alpha$-epoxyscillirosidine for $48 \mathrm{~h}$; (f) $100 \mu \mathrm{M}$ $1 \alpha, 2 \alpha$-epoxyscillirosidine for $72 \mathrm{~h}$. The organelles of untreated Neuro-2a cells appeared normal, with round or slightly convoluted nuclei. Cells exposed to $1 \alpha, 2 \alpha$-epoxyscillirosidine were extensively vacuolated, with swollen RER and perinuclear spaces. The cristae of some mitochondria were ballooned, and the nuclei were radially segmented. Many autophagic vesicles could be seen within the cytoplasm (blue arrow heads). G-Golgi complexes; M-Mitochondria; N-Nuclei; R-Rough Endoplasmic Reticulum. The scale bar at the bottom right corner represents $5 \mu \mathrm{m}(\mathbf{b}, \mathbf{c}), 2 \mu \mathrm{m}(\mathbf{a}, \mathbf{d}), 1 \mu \mathrm{m}(\mathbf{f})$ and $0.5 \mu \mathrm{m}(\mathbf{e})$ respectively.

In general, lanceotoxin B caused the Golgi complexes and mitochondria of the Neuro-2a cells to swell (Figure $6 \mathrm{a}, \mathrm{b}, \mathrm{e})$. The RER remained unaffected, except at $24 \mathrm{~h}$ in Neuro-2a cells exposed to $5 \mu \mathrm{M}$ lanceotoxin B (Figure 6a). Similarly, lanceotoxin B caused the perinuclear space of the nuclei to become swollen (red arrows; Figure $6 \mathrm{~b}$ ) at that concentration for $24 \mathrm{~h}$ exposure. The nuclei remained unaffected otherwise. Many cells were shrunken and rounded, forming membrane blebs (pink arrows; Figure $6 \mathrm{c}$ ) and some showing plasma membrane damage. The number of autophagic vesicles (blue arrow heads; Figure $6 \mathrm{~d}-\mathrm{f}$ ) in the affected cells increased in number. Large portions of the cell cytoplasm were sequestered in autophagic vesicles. Additionally, some of the autophagic vesicles extruded their content to the outside of the cell (cyan arrow; Figure 6e). 


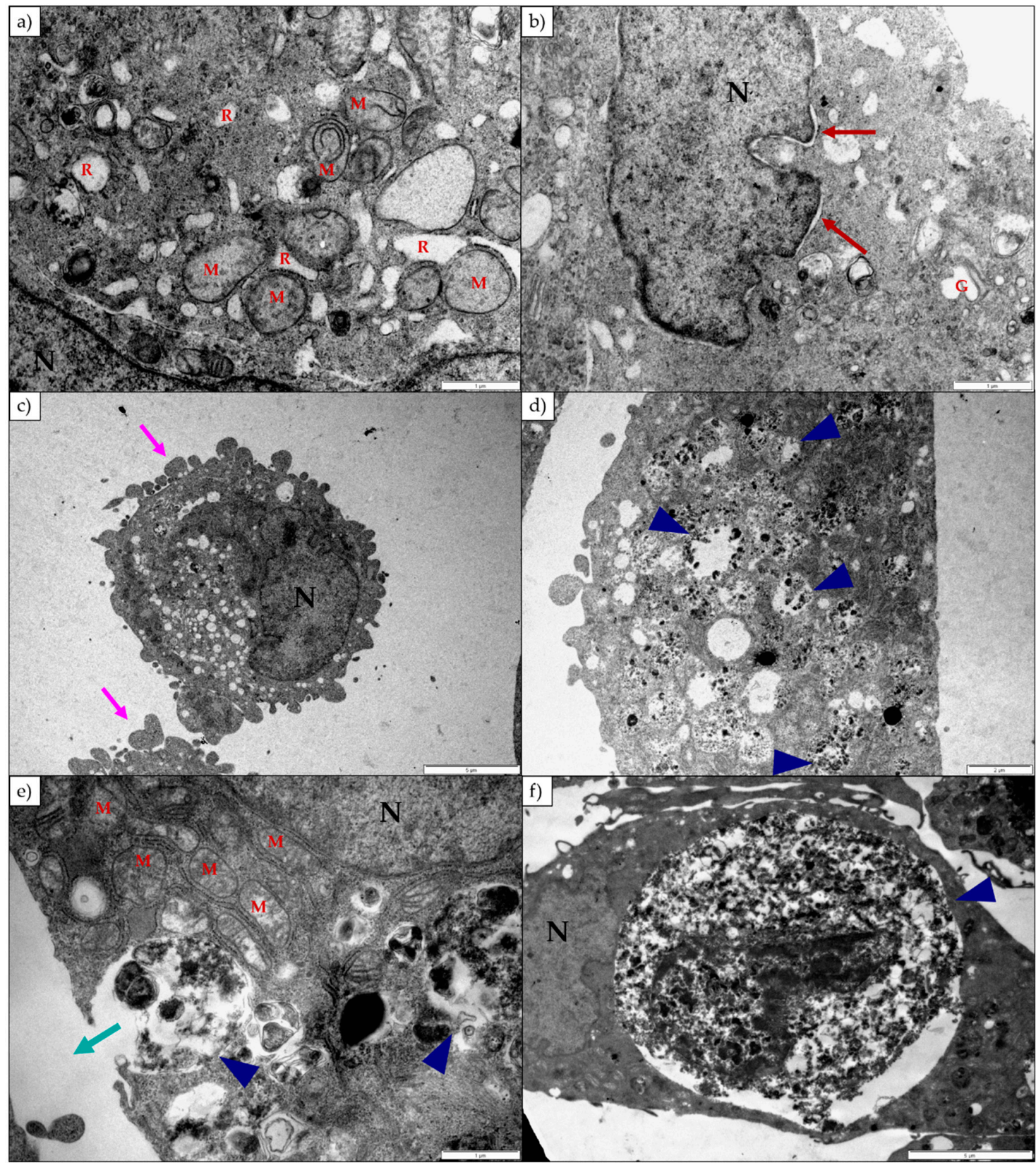

Figure 6. Electron micrograph of Neuro-2a cells exposed to (a,b) $5 \mu \mathrm{M}$ and (c,d) $25 \mu \mathrm{M}$ lanceotoxin B for $24 \mathrm{~h}$; (e) $100 \mu \mathrm{M}$ lanceotoxin B for $48 \mathrm{~h}$; (f) $25 \mu \mathrm{M}$ lanceotoxin B for $72 \mathrm{~h}$. Cells had membrane blebs (pink arrows). At $5 \mu \mathrm{M}$ after 24 h exposure cells showed swollen RER and perinuclear spaces. The mitochondria were grossly swollen $(\mathbf{a}, \mathbf{e})$. Cell content was sequestered in autophagic vesicles (blue arrow heads) and appeared to be released to the outside of the cells (cyan arrow). G-Golgi Complexes; M-Mitochondria; N-Nuclei; R-Rough Endoplasmic Reticulum. The scale bar at the bottom right corner represents $5 \mu \mathrm{m}(\mathbf{c}, \mathbf{f}), 2 \mu \mathrm{m}(\mathbf{d})$ and $1 \mu \mathrm{m}(\mathbf{a}, \mathbf{b}, \mathbf{e})$ respectively.

\section{Discussion}

Due to the paretic/paralytic nature of chronic intoxication in small stock, the cumulative bufadienolides are often referred to as neurotoxic. We thus compared the in vitro cytotoxicity of a cumulative bufadienolide, i.e., lanceotoxin B with a non-cumulative bufadienolide, $1 \alpha, 2 \alpha$ epoxyscillirosidine on both myocardial (H9c2) and neuroblastoma (Neuro-2a) cell lines (Table 1). The H9c2 cells were more susceptible to $1 \alpha, 2 \alpha$-epoxyscillirosidine with the $\mathrm{EC}_{50}$ of lanceotoxin B being more than five times greater than that of $1 \alpha, 2 \alpha$-epoxyscillirosidine after $24 \mathrm{~h}$ exposure. 
In contrast, lanceotoxin $\mathrm{B}$ had $\mathrm{EC}_{50} \mathrm{~s}$ below $6 \mu \mathrm{M}$ at all three exposure times when Neuro-2a cells were assessed, also being much lower than the $\mathrm{EC}_{50} \mathrm{~s}$ of $1 \alpha, 2 \alpha$-epoxyscillirosidine, ranging from 35.7 to $37.6 \mu \mathrm{M}$. These results support the theory that lanceotoxin B is neurotoxic, as lanceotoxin B induced greater cytotoxicity towards nerve cells. The neurotoxicity of the cumulative bufadienolides are believed to be due to their stereochemistry that differs from that of non-cumulative bufadienolides and cardenolides [10]. Unlike the other cardiac glycosides, cumulative bufadienolides have a levorotatory sugar strongly attached to the C3 position of the aglycone that cannot be removed by acid hydrolysis [10].

Of note, low concentrations of $1 \alpha, 2 \alpha$-epoxyscillirosidine had a positive effect on cell survival of both the $\mathrm{H} 9 \mathrm{c} 2$ and Neuro-2a cell lines, showing a possible hormetic effect. Similar results have previously been reported when using low concentrations of the cardenolide, ouabain [11,12]. The toxicity of the bufadienolides falling within the micromolar range was not unexpected as rodent cells are less susceptible to cardiac glycosides compared to other animals [13,14].

The ultrastructural changes observed in both $\mathrm{H} 9 \mathrm{c} 2$ and Neuro-2a cells exposed to $1 \alpha, 2 \alpha-$ epoxyscillirosidine included swollen Golgi complexes, RER and enlarged perinuclear space (Figures 3 and 5). These swollen organelles can be ascribed to the disruption of the ionic homeostasis of the cells caused by the bufadienolide. The RER and perinuclear space act as a storage site for intracellular calcium. The increased concentration of intracellular $\mathrm{Na}^{+}$and $\mathrm{Ca}^{2+}$ ions are accompanied by the influx of water, causing the organelles to swell. In addition to mitochondrial damage, $1 \alpha, 2 \alpha-$ epoxyscillirosidine caused some of the mitochondrial cristae to become slightly ballooned (Figure 5e), while the mitochondrial matrix remained unchanged. The inner and outer mitochondrial membranes have different permeability capacities thus causing the cristae and matrix to swell separately or subsequently. Exposure to $1 \alpha, 2 \alpha$-epoxyscillirosidine also caused large scale vacuolation of the cytoplasm (Figures 3 and 5), also possibly due to the disruption of the ion homeostasis of the cell. These vacuoles seem to originate from the Golgi complexes and the RER. The swollen RER, in addition to the dissociated ribosomes clumping within the cytoplasm, suggested that protein synthesis was disrupted.

Lanceotoxin B caused the Golgi complexes of both $\mathrm{H} 9 \mathrm{c} 2$ and Neuro-2a cells to swell, also conceivably due to the disruption of the sodium, potassium and calcium homeostasis of the cells. However, in contrast to cells exposed to $1 \alpha, 2 \alpha$-epoxyscillirosidine, the RER of the H9c2 cells remained unaffected. The RER and nuclei of the Neuro-2a cells also remained mostly unaffected. The mitochondrial matrix of both $\mathrm{H} 9 \mathrm{c} 2$ and Neuro-2a cells became grossly swollen after exposure to lanceotoxin B (Figures 4 and 6). The swelling, as mentioned above, is due to the influx of water that accompanies the increased ion concentrations. The cytoskeleton associated with the plasma membrane of the $\mathrm{H} 9 \mathrm{c} 2$ cells were also affected. Calcium activates different proteases, and these can subsequently degrade the cytoskeleton [15]. Lanceotoxin B caused a noticeable increase in the number of autophagic vesicles within the cytoplasm of affected cells. This was especially apparent in Neuro-2a cells, with large parts of the cells sequestered (Figure 6). Autophagy has historically been classified as a type of cell death, however its role in cell death is often misinterpreted [16]. Cells induce autophagy as a survival mechanism and often cell death is cell death with autophagy opposed to cell death by autophagy. Autophagy and neuronal cell death have previously been linked [17,18], thus corroborating the contention that lanceotoxin B is neurotoxic. The H9c2 cells exposed to lanceotoxin B were apoptotic, with shrunken, rounded cells; many with membrane blebs or what appears to be apoptotic bodies. In contrast, Neuro-2a cells exposed to lanceotoxin B, besides the extensive autophagy, also showed signs of both apoptosis and necrosis. The mixed morphological signs of cell death could be as a result of the various cellular pathways disrupted by the bufadienolides.

In future, molecular studies can be performed to clarify the type of cell death caused by these cumulative bufadienolides which will contribute to our understanding of the mechanism of toxicity underlying 'krimpsiekte'. In addition, investigating the ultrastructural changes in appropriate cells from poisoned animals and cells believed to not be affected by these bufadienolides could be of interest. 


\section{Materials and Methods}

\subsection{Cell Cultures}

Rat myocardial (H9c2(2-1) (ATCC ${ }^{\circledR}$ CRL-1446 $\left.{ }^{\mathrm{TM}}\right)$ ) and mouse neuroblastoma (Neuro-2a (ATCC ${ }^{\circledR}$ CRL-131 ${ }^{\mathrm{TM}}$ )) cell lines were obtained from the ATCC (American Type Culture Collection). The cultures were grown in HyClone DMEM (Dulbecco's Modified Eagle's Medium)-High Glucose, supplemented with $4 \mathrm{mM}$ glutamine, $1 \mathrm{mM}$ sodium pyruvate, 10\% fetal calf serum (Gibco, Life technologies, Carlsbad, CA, USA), $100 \mathrm{U} / \mathrm{mL}$ penicillin and $100 \mathrm{U} / \mathrm{mL}$ streptomycin (Lonza, Verviers, Belgium). The cells were maintained in an incubator at $37^{\circ} \mathrm{C}$ and a humidified atmosphere of $5 \% \mathrm{CO}_{2}$.

\subsection{Toxins}

$1 \alpha, 2 \alpha$-Epoxyscillirosidine and lanceotoxin B (>95\% purity) used in this study were previously isolated from $M$. pallida and K. lanceolata respectively and were preserved in dried form and stored in a secure place as part of the natural toxin collection of the Department of Paraclinical Sciences, Faculty of Veterinary Science, Onderstepoort. The stock solutions of $1 \alpha, 2 \alpha$-epoxyscillirosidine were prepared in a 1:1 organic solvent-complete DMEM media mixture using acetone, while stock solutions for lanceotoxin B were prepared in DMSO (dimethyl sulfoxide).

\subsection{Cell Survival Assays}

The percentage cell survival of $\mathrm{H} 9 \mathrm{c} 2$ and Neuro-2a cells after exposure to either $1 \alpha, 2 \alpha-$ epoxyscillirosidine or lanceotoxin B was determined using the MTT assay [19]. The cells were seeded into a 96 well plates at a concentration of 5000 cells/well for the Neuro-2a cells and 10,000 cells/well for the H9c2 cells, respectively in $200 \mu \mathrm{L}$ complete media per well, $24 \mathrm{~h}$ prior to the commencement of the exposure study. The cells were exposed to a $2 \times$ serial dilution of $1 \alpha, 2 \alpha$-epoxyscillirosidine and lanceotoxin B for 24, 48 and $72 \mathrm{~h}$. The percentage solvent was kept constant for all dilutions at $0.5 \%$ solvent/well. After termination of the exposure studies and following rinsing of the wells with $200 \mu \mathrm{L}$ PBS (phosphate buffered saline), pH 7.4, $20 \mu \mathrm{L}$ 0.005 g/mL Thiazolyl Blue Tetrazolium Bromide dissolved in PBS (Sigma-Aldrich, St. Louis, MO, USA) and $200 \mu \mathrm{L}$ complete DMEM media were added to each well. The plates were then incubated in the dark at $37{ }^{\circ} \mathrm{C}$ for $2 \mathrm{~h}$, the MTT medium replaced with $100 \mu \mathrm{L}$ DMSO and shaken for $5 \mathrm{~min}$ in the dark to solubilize the MTT formazan crystals. The absorbance of the MTT product was measured at $570 \mathrm{~nm}$ and the background at $630 \mathrm{~nm}$ using a Synergy HT BioTek microplate reader (BioTek Instruments, Inc., Winooski, VT, USA).

\subsection{Statistical Analysis}

Data were analyzed using Microsoft Excel (Office 365, Microsoft, Redmond, WA, USA) and GraphPad Prism (Version 6.0, GraphPad Prism Software Inc., La Jolla, CA, USA). All repeats of the assays were grouped together, and the outliers removed. The data was tested for compliance with normality and homogeneous variance using D'Agostino and Pearson omnibus normality tests and Bartlett's test, respectively. An ANOVA (factorial analysis of variance) was used to see if there were significant differences $(p>0.05)$ between the $\mathrm{EC}_{50} \mathrm{~s}$ at the different exposure periods; and in the case that there were, Student's t-test was used. The $95 \%$ confidence intervals were calculated by the following equation:

$95 \%$ CI $=$ Average cell survival at highest concentration of lanceotoxin B $\pm(1.96 \times$ Standard error of the mean).

\subsection{Transmission Electron Microscopy}

The ultrastructural changes induced by the toxins on H9c2 and Neuro-2a cells were investigated using TEM. H9c2 and Neuro-2a cells were exposed to 5, 25 and $100 \mu \mathrm{M} 1 \alpha, 2 \alpha$-epoxyscillirosidine and lanceotoxin B for 24, 48 and $72 \mathrm{~h}$. After termination of the exposure, the cells were fixed with 
$2.5 \%$ glutaraldehyde in $0.0075 \mathrm{M}$ sodium phosphate buffer $(\mathrm{pH} 7.4)$ for $1 \mathrm{~h}$. The cells were scraped off from the plate, centrifuged at $950 \mathrm{~g}$ and rinsed three times for $10 \mathrm{~min}$ with $0.075 \mathrm{M}$ phosphate buffer. The cells were post-fixed with osmium tetroxide and rinsed with the phosphate buffer for $10 \mathrm{~min}$. The cells were serially dehydrated in $30 \%, 50 \%, 70 \%, 90 \%$ and three times in $100 \%$ ethanol. The samples were then imbedded in TAAB 812 epoxy resin [20] and sectioned using an ultra-microtome (Leica EM UC7). Each section was contrasted with $2 \%$ aqueous uranyl acetate for $10 \mathrm{~min}$ and lead citrate for 2 min [21]. The sections were examined using a Philips CM10 Transmission Electron Microscope (Philips, Amsterdam, The Netherlands).

Author Contributions: A.V., C.B. and D.H. conceived and designed the experiments; D.H. performed the experiments and analyzed the data; C.B. contributed reagents/materials/analysis tools; D.H. wrote the paper; A.V. and C.B. edited the paper.

Funding: This research received no external funding.

Acknowledgments: We would like to thank Chris van der Merwe for preparing the samples for the TEM.

Conflicts of Interest: The authors declare no conflict of interest.

\section{References}

1. Kellerman, T.; Naudé, T.; Fourie, N. The distribution, diagnoses and estimated economic impact of plant poisonings and mycotoxicoses in South Africa. Onderstepoort J. Vet. Res. 1996, 63, 65-90. [PubMed]

2. Kellerman, T.; Coetzer, J.; Naudé, T.; Botha, C. Plant Poisonings and Mycotoxicoses of Livestock in Southern Africa; Oxford University Press Southern Africa: Cape Town, South Africa, 2005.

3. Enslin, P.; Naudé, T.; Potgieter, D.; Van Wyk, A. $1 \alpha, 2 \alpha$-epoxyscillirosidine, the main toxic principle of Homeria glauca (Wood and Evans) NE Br. Tetrahedron 1966, 22, 3213-3220. [CrossRef]

4. Anderson, L.; Schultz, R.; Joubert, J.; Prozesky, L.; Kellerman, T.; Erasmus, G.; Procos, J. Krimpsiekte and acute cardiac glycoside poisoning in sheep caused by bufadienolides from the plant Kalanchoe lanceolata Forsk. Onderstepoort J. Vet. Res. 1983, 50, 295-300. [PubMed]

5. Riganti, C.; Campia, I.; Kopecka, J.; Gazzano, E.; Doublier, S.; Aldieri, E.; Bosia, A.; Ghigo, D. Pleiotropic effects of cardioactive glycosides. Curr. Med. Chem. 2011, 18, 872-885. [CrossRef] [PubMed]

6. Contreras, R.; Flores-Maldonado, C.; Lazaro, A.; Shoshani, L.; Flores-Benitez, D.; Larre, I.; Cereijido, M. Ouabain Binding to $\mathrm{Na}^{+}, \mathrm{K}^{+}$-ATPase Relaxes Cell Attachment and Sends a SpecificSignal (NACos) to the Nucleus. J. Membr. Biol. 2004, 198, 147-158. [CrossRef] [PubMed]

7. Contreras, R.; Shoshani, L.; Flores-Maldonado, C.; Lazaro, A.; Cereijido, M. Relationship between Na (+), K (+)-ATPase and cell attachment. J. Cell Sci. 1999, 112, 4223-4232. [PubMed]

8. Botha, C.; Gehring, R.; Van Rooyen, J.; Venter, D. The effect of three bufadienolide cardiac glycosides on contraction of isolated rat jejunum. Onderstepoort J. Vet. Res. 2002, 69, 243-246. [PubMed]

9. Botha, C.J.; Van der Lugt, J.J.; Erasmus, G.; Kellerman, T.S.; Schultz, R.A.; Vleggaar, R. Krimpsiekte, associated with thalamic lesions, induced by the neurotoxic cardiac glycoside, cotyledoside, isolated from Tylecodon wallichii (Harv.) Toelken subsp. wallichii. Onderstepoort J. Vet. Res. 1997, 64, 189-194. [PubMed]

10. Botha, C. Potential health risks posed by plant-derived cumulative neurotoxic bufadienolides in South Africa. Molecules 2016, 21, 348. [CrossRef] [PubMed]

11. Li, J.; Zelenin, S.; Aperia, A.; Aizman, O. Low doses of ouabain protect from serum deprivation-triggered apoptosis and stimulate kidney cell proliferation via activation of NF-kB. J. Am. Soc. Nephrol. 2006, 17, 1848-1857. [CrossRef] [PubMed]

12. Peng, M.; Huang, L.; Xie, Z.; Huang, W.-H.; Askari, A. Partial inhibition of Na/K-ATPase by ouabain induces the Ca-dependent expressions of early-response genes in cardiac myocytes. J. Biol. Chem. 1996, 271, 10372-10378. [CrossRef] [PubMed]

13. Price, E.M.; Lingrel, J.B. Structure-function relationships in the sodium-potassium ATPase. alpha. subunit: Site-directed mutagenesis of glutamine- 111 to arginine and asparagine- 122 to aspartic acid generates a ouabain-resistant enzyme. Biochemistry 1988, 27, 8400-8408. [CrossRef] [PubMed]

14. Weinhouse, E.; Kaplanski, J.; Posner, J. Comparison of digoxin-induced cardiac toxicity in resistant and sensitive species. J. Pharm. Pharmacol. 1983, 35, 580-583. [CrossRef] [PubMed] 
15. Dong, Z.; Saikumar, P.; Weinberg, J.M.; Venkatachalam, M.A. Calcium in cell injury and death. Annu. Rev. Pathol. Mech. Dis. 2006, 1, 405-434. [CrossRef] [PubMed]

16. Kroemer, G.; Levine, B. Autophagic cell death: The story of a misnomer. Nat. Rev. Mol. Cell Biol. 2008, 9, 1004-1010. [CrossRef] [PubMed]

17. Botella, J.; Kretzschmar, D.; Kiermayer, C.; Feldmann, P.; Hughes, D.; Schneuwly, S. Deregulation of the Egfr/Ras signaling pathway induces age-related brain degeneration in the Drosophila mutant vap. Mol. Biol. Cell 2003, 14, 241-250. [CrossRef] [PubMed]

18. Kitanaka, C.; Kato, K.; Ijiri, R.; Sakurada, K.; Tomiyama, A.; Noguchi, K.; Nagashima, Y.; Nakagawara, A.; Momoi, T.; Toyoda, Y. Increased Ras expression and caspase-independent neuroblastoma cell death: Possible mechanism of spontaneous neuroblastoma regression. Nat. Cancer Inst. 2002, 94, 358-368. [CrossRef]

19. Mosmann, T. Rapid colorimetric assay for cellular growth and survival: Application to proliferation and cytotoxicity assays. J. Immunol. Methods 1983, 65, 55-63. [CrossRef]

20. Luft, J. Improvements in epoxy resin embedding methods. J. Cell Biol. 1961, 9, 409-414. [CrossRef]

21. Reynolds, E. The use of lead citrate at high $\mathrm{pH}$ as an electron-opaque stain in electron microscopy. J. Cell Biol. 1963, 17, 208-212. [CrossRef] [PubMed]

(C) 2019 by the authors. Licensee MDPI, Basel, Switzerland. This article is an open access article distributed under the terms and conditions of the Creative Commons Attribution (CC BY) license (http://creativecommons.org/licenses/by/4.0/). 